\title{
Pengukuran perilaku dan niat beli produk kosmetik halal melalui modifikasi theory of planned behavior (TPB)
}

\author{
Justi Aresta Kadengkang', Utaminingsih Linarti ${ }^{2}$ \\ ${ }^{1,2}$ Fakultas Teknologi Industri, Universitas Ahmad Dahlan, Indonesia
}

\begin{tabular}{l}
\hline Info Artikel \\
\hline Sejarah Artikel: \\
Diterima \\
29 Juni 2019 \\
Direview \\
I0 September 2019 \\
Disetujui \\
07 Februari 2020 \\
Dipublikasikan \\
27 Februari 2020 \\
\hline Keywords: \\
cosmetics, \\
halal, \\
product knowledge, \\
religiosity, \\
theory of planned behavior
\end{tabular}
\begin{abstract}
Abstrak
Objektif: tujuan dari penelitian ini adalah untuk mengetahui pengaruh sikap, norma subyektif dan kontrol persepsi yang dimodifikasi dengan religiusitas, dan pengetahuan produk terhadap niat beli dan perilaku konsumen muslim dalam membeli produk kosmetik halal

Metode: subjek dalam penelitian ini adalah mahasiswa muslim berusia 1723 tahun yang sedang menempuh pendidikan di Perguruan Tinggi Negeri (PTN) di Provinsi Daerah Istimewa Yogyakarta. Teknik sampling menggunakan purposive sampling. Metode analisis yang digunakan yaitu regresi linear berganda. Pengumpulan data menggunakan kuisoner tertutup dengan jumlah sampel sebanyak 275 sampel.
\end{abstract}

Temuan: hasil temuan dari penelitian ini menunjukan bahwa religiusitas, pengetahuan produk, sikap, norma subjektif dan kontrol presepsi memiliki pengaruh positif dan signifikan terhadap niat konsumen dalam membeli produk kosmetik yang halal.

Kesimpulan: diharapkan untuk selalu memperhatikan dan mengetahui label halal dan kandungan yang terkandung pada setiap produk kosmetik yang akan digunakan sehingga dapat terhindar dari produk yang tidak halal atau memiliki kandungan yang diharamkan oleh agama.

\section{Measuring Behavior and Intention to Buy Halal Cosmetic Products Through Modification of Theory of Planned Behavior (TPB)}

Objectives: the purpose of this study was to study the relationship attitudes, subjective norms and perceptual controls related to religiosity, and product knowledge about the purpose of buying and helping Muslim consumers in buying halal cosmetic products.

Method: the subject in this study was Muslim students aged 17-23 years who were studying at State Universities (PTN) in the Province of Daerah Istimewa Yogyakarta. The sampling technique uses purposive sampling. The analytical method used is multiple linear regression. Data collection uses a closed questionnaire with a total of 275 respondents.

Findings: the findings of this study indicate that religiosity, product knowledge, attitudes, subjective norms, and perception control have a positive and significant influence on consumers' intentions in buying halal cosmetic products

Conclusions: it is expected to always pay attention and know the halal label and the content on the cosmetic products to be used, so as to avoid products that are not halal or have content that is prohibited by religion.

\footnotetext{
*Alamat korespondensi:

Kampus I, Universitas Ahmad Dahlan, Jl. Kapas 9, Semaki, Umbulharjo, Yogyakarta 55166

ljustil500019066@webmail.uad.ac.id, 2utaminingsih.linarti@ie.uad.ac.id
} 


\section{Pendahuluan}

Berdasarkan sensus penduduk yang dilakukan oleh Badan Pusat Statistik Indonesia (2010), Penganut Agama Islam di Indonesia sebesar 209, I juta jiwa atau sekitar 87,2\% dari total penduduk. Jumlah yang besar ini mengimplikasikan bahwa sekitar 13\% dari umat Muslim di seluruh dunia tinggal di Indonesia dan juga mengimplikasikan bahwa mayoritas populasi penduduk di Indonesia memeluk agama Islam. Besarnya jumlah persentase tersebut menjadi peluang bagi produk halal untuk berkembang di Indonesia. Sehingga Indonesia merupakan salah satu pasar kosmetik yang cukup prospektif dan menjanjikan bagi produsen yang ingin mengembangkannya di dalam negeri (kemenperin.go.id).

Menurut data Kementerian Perindustrian (2016), nilai ekspor produk kosmetik pada 2015 mencapai US\$ 8I8 juta atau Rp I I triliun. Sedangkan untuk nilai impornya mencapai US\$ 44 I juta. Akan tetapi, pasar kosmetik dalam negeri ini masih didominasi oleh industri multinasional dengan penguasaan pangsa pasar sekitar 70\%. Sementara itu menurut Future Market Insights (2015) pasar produk halal di Asia Tenggara diperkirakan akan berekspansi sebesar 10.2\% pada periode 2015 2020. Ketua Umum Persatuan Perusahaan Kosmetika Indonesia (PERKOSMI), Putri K Wardhani mengungkap kalau setiap tahun pasar kosmetik di indonesia selalu saja dibanjiri produk impor. Baik yang ilegal maupun legal. Produk ilegal tersebut masuk melalui pelabuhan tikus disekitar perbatasan negara kita. Itu terjadi secara terus menerus. Masalah industri kosmetik berasal dari ketentuan peredaran produk impor yang tidak memerlukan izin Badan Pengawas Obat Makanan (BPOM). Hal ini dinilai sangat membahayakan konsumen Indonesia.

Majelis Ulama Indonesia (MUI) mengungkapkan bahwa semua produk yang dianggap meragukan harus di teliti terlebih dahulu sebelum menetapkan produk tersebut sebagai produk halal. Hal tersebut dibutuhkan untuk meningkatkan keyakinan konsumen terhadap produk halal tersebut (Aisyah, 2015). Lembaga Pengkajian Pangan Obat-Obatan dan Kosmetika MUI - LPPOM MUI (2016), mengungkapkan bahwa pada tahun 2015 terdapat 907 produk kosmetik yang telah memiliki sertifikasi halal. Jumlah kosmetik yang memiliki sertifikasi halal dapat dilihat melalui daftar produk halal yang dipublikasikan oleh LPPOM MUI setiap tahunnya melalui website resmi LPPOM MUI. Berdasarkan daftar produk halal tahun 2016, jumlah produk kosmetik yang memiliki sertifikasi halal terus bertambah dari tahun sebelumnya.

Kosmetik dikatakan halal bila dalam proses produksi tidak menggunakan zat-zat yang diharamkan oleh islam seperti terdapat kandungan unsur dari babi, anjing atau binatang buas, manusia, darah, bangkai dan alkohol. Selain itu bahan yang halal pada produk kosmetik juga dapat membuat air wudhu meresap ke dalam kulit (Saliha.id). Perintah untuk mengkonsumsi yang halal dan tidak menyentuh barang yang haram bagi umat Muslim telah dijelaskan dalam kitab suci Al-Qur'an dan Al-Hadits seperti pada Q.S. Al Baqarah: 168 dan QS. An-Nahl/I6:I I 4 (Endah, 20I8).

Theory of Planned Behaviour merupakan teori umum yang digunakan untuk menjelaskan bagaimana suatu perilaku dapat terbentuk. Selain itu, Endah (2018) menielaskan pula bahwa model proses kognisi juga dapat digunakan untuk menjelaskan bagaimana suatu perilaku dapat terbentuk. Kedua model tersebut memiliki asumsi yang sama yaitu perilaku yang dimaksud adalah perilaku yang dilakukan secara sadar atau dalam kasus ini bukan merupakan impulsive buying. Sehingga dapat dinyatakan bahwa proses pengambilan keputusan dalam membeli produk diawali dengan adanya informasi yang dimiliki oleh konsumen yang kemudian diinterpretasikan pada kognisi, yaitu attention dan comprehension. Attention merupakan kognisi dimana informasi apasaja yang diperlukan sedangkan comprehension merupakan kognisi konsumen menentukan makna subjektif yang menciptakan pengetahuan dan keyakinan (beliefs). Attitude menggambarkan hasil evaluasi terhadap suatu entitas (objek maupun perbuatan) apakah dia suka atau tidak suka (Aizen, 2005). Seseorang akan cenderung memiliki niat untuk melakukan sesuat jika kegiatan tersebut adalah hal yang disukai. Niat tersebut akan membentuk seseorang untuk membentuk perilaku seseorang (Endah, 20I8) 
Berdasarkan beberapa penelitian Ahmad, Rahman, \& Rahman, (2015); Haque, Anwar, Tarofder, Ahmad, \& Syarif, (2018); Aditami, (2016); Briliana \& Noviana, (2016); Rohmatun \& Dewi, (2017); Larasati, et.al, (20l8), yang berhubungan dengan niat pembelian sebuah produk halal, ditemukan bahwa penggunaan Theory of Planned Behavior masih menjadi pilihan sebagai dasar untuk mengukur seberapa besar niat yang muncul, dan juga untuk mengetahui pengaruh dari beberapa faktor yang menjadi anteseden dari teori tersebut, yaitu seperti sikap, norma subjektif, dan kontrol dalam berperilaku (Suparno, 2017). Menurut Ajzen (2005) Theory of Planned Behavior sangat terbuka untuk ditambah variabel prediktor lain dalam memprediksi niat dan perilaku tentang objek yang diteliti.

Karena permintaan produk kosmetik halal semakin meningkat seperti yang sudah dijelaskan sebelumnya maka produsen harus sepenuhnya memahami faktor-faktor yang dapat mempengaruhi niat dan perilaku pembelian kosmetik halal di kalangan konsumen Muslim. Dengan memiliki pengetahuan di bidang ini, produsen akan dapat menghasilkan produk kosmetik halal yang mampu memenuhi kebutuhan dan preferensi konsumen Muslim.

Dapat diasumsikan bahwa semakin tinggi individu memasukkan agama ke dalam identitasnya, semakin besar dampaknya terhadap nilai dan perilaku mereka. Menurut Ahmad et al., (2015) religiusitas adalah sejauh mana seorang individu berkomitmen pada agamanya yang tercermin pada sikap dan perilakunya Religiusitas dapat digambarkan sebagai konsistensi antara kepercayaan terhadap agama sebagai unsur kognitif, perasaan agama sebagai unsur efektif dan perilaku terhadap agama sebagai unsur psikomotorik. Oleh karena itu, religiusitas juga bisa berdampak pada pilihan dan keputusan yang dibuat individu. Secara keseluruhan, religiusitas ditemukan memiliki pengaruh terhadap kepercayaan seseorang, pengetahuan, sikap, apa yang disukai dan tidak sukai, serta perasaan seseorang tentang konsumsi (Farrag \& Hassan, 2015). Pada penelitian Rohmatun \& Dewi (20I7); Haque et al. (20I8); Rois (20I6) menyatakan bahwa religiusitas memiliki pengaruh positif dan signifikan terhadap niat membeli produk kosmetik halal.

Pengetahuan produk juga menjadi faktor yang mempengaruhi sikap dan perilaku konsumen dalam membeli. Menurut Rochmanto \& Widiyanto (2015) pengetahuan produk adalah pengetahuan konsumen yang berkaitan dengan pengetahuan tentang ciri atau karakter produk, konsekuensi menggunakan produk dan nilai (tingkat) kepuasan yang akan dicapai oleh produk. Pengetahuan konsumen tentang suatu produk dapat mempengaruhi kepuasan secara positif. Pernyataan ini didukung oleh penelitian Rois, (2016) dan Rohmatun \& Dewi (2017) yang menyatakan bahwa pengetahuan produk memiliki pengaruh positif dan signifikan terhadap niat membeli produk kosmetik halal.

Tujuan dari penelitian ini adalah untuk menyelidiki faktor-faktor mana saja yang berpengaruh terhadap niat beli dan perilaku pembelian produk kosmetik halal di kalangan konsumen muslim dan untuk mengetahui hubungan antara sikap, norma subyektif, persepsi kontrol perilaku, religiusitas, pengetahuan produk, dan niat beli produk kosmetik terhadap perilaku konsumen muslim dalam membeli produk kosmetik halal.

\section{Metode}

Penelitian ini diharapkan dapat memberikan pemahaman menyeluruh terkait faktor-faktor yang dapat mempengaruhi perilaku konsumen Muslim dalam membeli kosmetik halal menggunakan pendekatan kuantitatif. Populasi yang menjadi target pada penelitian ini yaitu mahasiswa muslim berusia 17-23 tahun yang sedang menempuh pendidikan di Perguruan Tinggi Negeri (PTN) di bawah naungan Kementrian Riset, Teknologi Pendidikan Tinggi Republik Indonesia di Provinsi Daerah Istimewa Yogyakarta (DIY) yaitu Universitas Gadjah Mada (UGM), Universitas Negeri Yogyakarta (UNY), dan Universitas Pembangunan Nasional (UPN) Veteran Yogyakarta. Teknik pengambilan sampel yang digunakan pada penelitian ini yaitu purposive sampling. Metode analisis yang digunakan pada penelitian ini yaitu regresi linear berganda. Pengumpulan data menggunakan 
kuisoner tertutup dengan jumlah sampel sebanyak 275 sampel. Sebelum kuisoner disebar, dilakukan uji face validity terlebih dahulu oleh tiga orang validator yang berkompeten dalam topik penelitian ini untuk menentukan kuisoner sudah sesuai dan layak untuk dibagikan kepada responden. Kemudian kuesioner yang telah disebarkan kepada responden akan dilakukan pengujian validitas konstruk dan reliabilitas. Sebelumnya, hasil data responden dilakukan examination data, yaitu: (I) Identifikasi missing data dan (2) data outlier (Hair, et.al, 2007).

Penelitian ini mengacu pada model dasar (Ajzen, 2005) yaitu TPB yang memiliki komponen variabel Sikap (Attitude), Norma subjektif (Subjective norm), Kontrol Presepsi (Perceived Behavioral Control), Niat (Intention) dan Perilaku (Behavior). Kemudian peneliti melakukan modifikasi dengan menambahkan variabel yaitu religiusitas dan pengetahuan produk yang mengacu pada model penelitian Ahmad et al. (20I5); Haque et al. (20l8); Aditami (2016); Briliana \& Noviana (2016); (Rohmatun \& Dewi, 2017); Larasati et al. (2018). Gambar I merupakan model konseptual dalam penelitian ini.

\section{Gambar I. Model konseptual penelitian}

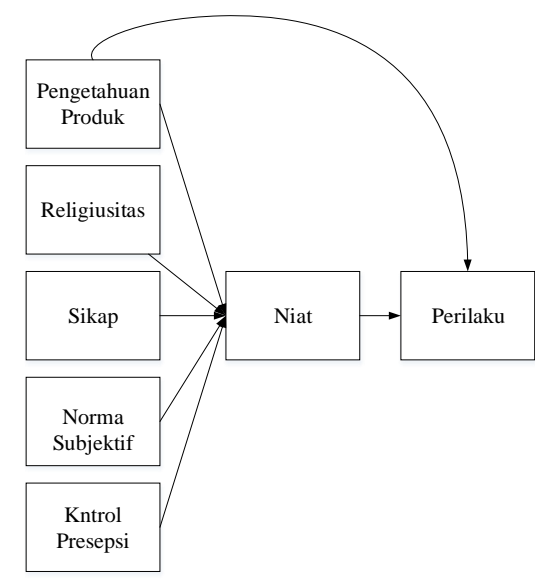

\section{Hasil}

Pengolahan data pada penelitian ini terdiri dari 4 tahap tahapan yaitu uji reabilitas, uji validitas, uji asumsi klasik yang terdiri dari uji normalitas, uji heteroskedastisitas dan uji multikolinieritas. Selanjutkan dilakukan uji analisis regresi berganda atau analisis hasil hipotesis. Berdasarkan model penelitian pada gambar I, uji analisis regresi tidak dilakukan secara simultan namun secara parsial. Terdapat dua tahapan yang dilakukan yaitu, (I) Pengukuran niat konsumen dalam membeli produk kosmetik halal dan (2) Pengukuran perilaku konsumen dalam membeli produk kosmetik halal. Tidak dilakukan pengujian terhadap model struktural teoritis.

Tahap pertama yang dilakukan dalam penelitian ini yaitu uji reliabilitas. Uji reabilitas digunakan untuk mengukur suatu kuisoner yang merupakan indikator dari suatu variabel (Ghozali, 2018). Suatu kuesioner dikatakan reliable (layak) jika cronbach's alpha $>0,60$ dan dikatakan tidak reliable jika cronbach's alpha $<0,60$. Pada uji ini semua variabel memiliki hasil hitung Cronbach's Alpha $>$ 0,60 , sehingga dapat disimpulkan bahwa seluruh variabel yang digunakan dalam model penelitian ini dapat dikatakan reliable dan layak dijadikan sebagai alat ukur.

Tahap kedua yang dilakukan dalam penelitian ini yaitu uji validitas. Uji validitas data digunakan untuk mengukur sah atau valid tidaknya suatu kuesioner. Suatu kuesioner dikatakan valid jika pertanyaan pada kuesioner mampu untuk mengungkapkan suatu yang akan diukur oleh kuesioner tersebut. Pengujian validitas selain untuk mengetahui dan mengungkapkan data dengan tepat juga harus memberikan gambaran yang cermat mengenai data tersebut (Ghozali, 2018). Kuisoner dalam penelitian ini terdiri dari 50 butir pertanyaan yaitu 8 item pertanyaan mewakili variabel religiusitas, 6 item pertanyaan mewakili variabel pengetahuan produk, 7 item pertanyaan mewakili variabel sikap, 7 item pertanyaan mewakili variabel norma subjektif, 10 item pertanyaan mewakili variabel 
kontrol presepsi, 8 item pertanyaan mewakili variabel niat, dan 4 item pertanyaan mewakili variabel perilaku. Setelah dilakukan uji validitas dari 50 item pertanyaan terdapat 2 item pertanyaan yang tidak valid yaitu item pertanyaan pada variabel sikap dan kontrol presepsi. Sehingga peneliti melakukan perbaikan dengan menghilangkan kedua item pertanyaan tersebut.

Tahap ketiga pada penelitian ini yaitu uji asumsi klasik yang terdiri dari uji normalitas, uji heteroskedastisitas dan uji multikolineritas. Uji normalitas pada penelitian ini menunjukan bahwa sig. > $0.05(0.099>0.05)$, sehingga dapat disimpulkan data berdistribusi normal. Selanjutnya pada uji heteroskedastisitas menunjukan tidak terjadi gejala heteroskedatisitas karena titik residu menyebar secara acak diatas dan dibawah garis diagonal. Hal ini diperkuat dengan hasil sig. $>0.05$ yang artinya bahwa tidak terjadi heteroskedastisitas. Uji asumsi yang terakhir adalah uji multikolinearitas, berdasarkan hasil pengolahan data menunjukan bahwa nilai tolerance $\leq 0.10$ atau nilai VIF $\geq 10$ yang artinya tidak terjadi multikolinearitas pada data.

Tahap keempat pada penelitian ini adalah uji analisis regresi berganda atau analisis hasil hipotesis. Berdasarkan hasil analisis regresi linear berganda disimpulkan bahwa masing-masing variabel independent berpengaruh signifikan terhadap dependen. Hasil analisis hipotesis baik tahap (I) pengukuran terhadap niat konsumen membeli produk kosmetik halal maupun tahap (2) pengukuran terhadap perilaku konsumen membeli produk kosmetik halal ditunjukan pada tabel $\mathrm{I}$.

Tabel I. Hasil analisis hipotesis

\begin{tabular}{|c|c|c|c|c|}
\hline $\begin{array}{r}\text { Hipotesis } \\
\end{array}$ & B & $t$-value & Sig. & Kesimpulan \\
\hline $\begin{array}{l}\mathrm{H}_{1} \text { : Religiusitas berpengaruh signifikan terhadap } \\
\text { niat konsumen membeli produk kosmetik halal } \\
\mathrm{H}_{2} \text { : Pengetahuan produk berpengaruh signifikan }\end{array}$ & .178 & 2.264 & .024 & signifikan \\
\hline $\begin{array}{l}\text { terhadap niat konsumen membeli produk } \\
\text { kosmetik halal }\end{array}$ & .209 & 3.591 & .000 & signifikan \\
\hline $\begin{array}{l}\mathrm{H}_{3} \text { : Sikap berpengaruh signifikan terhadap niat } \\
\text { konsumen membeli produk kosmetik halal }\end{array}$ & .432 & 7.075 & .000 & signifikan \\
\hline $\begin{array}{l}\mathrm{H}_{4} \text { : Norma subjektif berpengaruh signifikan } \\
\text { terhadap niat konsumen membeli produk } \\
\text { kosmetik halal }\end{array}$ & .143 & 3.224 & .001 & signifikan \\
\hline $\begin{array}{l}\text { : Kontrol Presepsi berpengaruh signifikan } \\
\text { terhadap niat konsumen membeli produk } \\
\text { kosmetik halal }\end{array}$ & .109 & 2.151 & .032 & signifikan \\
\hline $\begin{array}{l}\mathrm{H}_{6} \text { : Pengetahuan produk berpengaruh signifikan } \\
\text { terhadap Perilaku konsumen membeli produk } \\
\text { kosmetik halal }\end{array}$ & .617 & 9.109 & .000 & signifikan \\
\hline $\begin{aligned} \mathrm{H}_{6} & \text { : Niat produk berpengaruh signifikan terhadap } \\
& \text { Perilaku konsumen membeli produk kosmetik } \\
& \text { halal }\end{aligned}$ & 1.101 & 15.810 & .000 & signifikan \\
\hline
\end{tabular}

\section{Pembahasan}

Berdasarkan hasil tabel uji analisis berganda diatas menunjukkan bahwa semua variabel independent religiusitas, pengetahuan produk, sikap, norma subjektif dan kontrol persepsi memiliki pengaruh signifikan terhadap variabel niat. Hasil ini mendukung hipotesis penelitian $\left(\mathrm{H}_{1}, \mathrm{H}_{2}, \mathrm{H}_{3}, \mathrm{H}_{4}\right.$ dan $\mathrm{H}_{5}$ ). Kemudian ini juga mendukung teori yang menyatakan bahwa pengetahuan berpengaruh signifikan terhadap perilaku. Hasil ini mendukung hipotesis penelitian $\left(\mathrm{H}_{6}\right.$ dan $\left.\mathrm{H}_{7}\right) . \mathrm{Hal}$ ini terlihat dari hasil sig. $<0.05$ yang artinya variabel independen berpengaruh secara signifikan terhadap variabel dependen.).

Hubungan masing-masing variabel menunjukkan bahwa semua variabel independent religiusitas, pengetahuan produk, sikap, norma subjektif dan kontrol persepsi memiliki hubungan yang positif terhadap variabel niat. Kemudian pengetahuan produk dan niat juga memiliki hubungan yang positif 
terhadap variabel perilaku. Hal ini terlihat dari hasil $B$ yang menunjukkan angka positif sehingga disimpulkan semua variabel independen memiliki hubungan positif dengan variabel dependen.

Penelitian ini juga menambahkan faktor diluar model konseptual Theory Planned of Behaviour yaitu faktor religiusitas dan pengetahuan produk. Menurut Ahmad et al. (2015) religiusitas menggambarkan sejauh mana seorang individu berkomitmen pada agamanya yang tercermin pada sikap dan perilakunya. Sedangkan Menurut Rochmanto \& Widiyanto (2015) pengetahuan produk adalah pengetahuan konsumen yang berkaitan dengan pengetahuan tentang ciri atau karakter produk, konsekuensi menggunakan produk dan nilai (tingkat) kepuasan yang akan dicapai oleh produk. Pengetahuan konsumen tentang suatu produk dapat mempengaruhi kepuasan secara positif.

Hasil dari pengolahan data telah menyatakan bahwa religiusitas dan pengetahuan produk berpengaruh signifikan terhadap niat konsumen dalam membeli produk kosmetik yang halal. Serta faktor pengetahuan produk juga menunjukan berpengaruh secara signifikan terhadap perilaku konsumen dalam membeli produk kosmetik yang halal. Hal ini didukung dengan hasil penelitian sebelumnya yaitu pada penelitian Rois (2016) Dan pada penelitian Rohmatun \& Dewi (2017), yang menyatakan bahwa religiusitas dan pengetahuan produk memiliki pengaruh positif dan signifikan terhadap niat membeli produk kosmetik halal. Serta pada penelitian Haque et al. (20/8) yang menyatakan bahwa sikap, kontrol perilaku dan religiusitas memiliki hubungan yang signifikan dengan niat pembelian produk kosmetik halal. sedangkan norma subjektif memiliki hubungan yang tidak signifikan.

\section{Kesimpulan}

Penelitian ini bertujuan untuk mengetahui pengaruh dan hubungan religiusitas, pengetahuan produk, sikap, norma subjektif dan kontrol presepsi terhadap niat konsumen dalam membeli produk kosmetik yang halal. Dan juga untuk mengetahui pengaruh dan hubungan pengetahuan produk terhadap perilaku tanpa melalui variabel niat. Dan yang terakhir untuk melihat pengaruh dan hubungan dari variabel niat ke perilaku konsumen dalam membeli produk kosmetik yang halal.

Temuan yang dihasilkan dari penelitian ini menunjukan bahwa religiusitas, pengetahuan produk, sikap, norma subjektif dan kontrol presepsi memiliki pengaruh positif dan signifikan terhadap niat konsumen dalam membeli produk kosmetik yang halal. Kemudian pengetahuan produk dan niat juga memiliki pengaruh positif dan signifikan terhadap perilaku konsumen dalam membeli produk kosmetik yang halal.

Implikasi dari penelitian ini kepada mahasiswa muslim yang menggunakan kosmetik diharapkan untuk selalu memperhatikan dan mengetahui label halal dan kandungan yang terkandung pada setiap produk kosmetik yang akan digunakan sehingga dapat terhindar dari produk yang tidak halal atau memiliki kandungan yang diharamkan oleh agama.

\section{REFERENSI}

Aditami, S. (2016). The Analysis Of Halal Product Purchase Intention Using Theory Of Planned Behavior ( TPB ): An Application On Bakery Product Consumption. Muhammadiyah University of Surakarta.

Ahmad, A. N., Rahman, A. A., \& Rahman, S. A. (2015). Assessing Knowledge and Religiosity on Consumer Behavior towards Halal Food and Cosmetic Products. International Journal of Social Science and Humanity, 5(I), 10-14.

Aisyah, M. (20I5). Peer Group Effects On Moslem Consumer'S Decision To Purchase HalalLabeled Cosmetics. Al-lqtishad Journal of Economic Islamic, (95), I65-I80. 
Ajzen, I. (2005). Attitudes, Personality and Behavior (2 edition; I. Ajzen, Ed.). New York: McGrawHill.

Briliana, V., \& Noviana, R. (2016). The Antecedents And Outcome Of Halal Cosmetic Products: A Case Study In Jakarta Indonesia. International Journal of Business, Economics and Law, I I (2), I9.

Endah, N. H. (2018). Perilaku Pembelian Kosmetik Berlabel Halal Oleh Konsumen Indonesia Consumers's Purchasing Behavior Toward Halal Labeled. Jurnal Ekonomi Dan Pembangunan, 22(I), II-25.

Farrag, D. A., \& Hassan, M. (2015). The Influence Of Religiosity On Egyptian Muslim Youths ' Attitude Towards Fashion. Journal of Islamic Marketing, 6(I), 95-108.

Ghozali, I. (2018). Aplikasi Analisis Multivariate dengan Program IBM SPSS 25. Semarang: Badan Penerbit Universitas Diponegoro.

Hair, J. F., Black, W. C., Babin, B. J., \& Anderson, R. E. (2007). Overview of Multivariate Methods. London, United Kingdom: Pearson.

Haque, A., Anwar, N., Tarofder, A. K., Ahmad, N. S., \& Syarif, S. R. (20I8). Muslim Consumers' Purchase Behavior Towards Halal Cosmetic Products In Malaysia. Management Science Letter, $8,1305-1318$.

Larasati, A., Rahayu, S., Hati, H., \& Safira, A. (2018). Religiusitas dan Pengetahuan Terhadap Sikap dan Intensi Konsumen Muslim untuk Membeli Produk Kosmetik Halal. 8(April), 105-II4.

Ramdhani, N. (20II). Penyusunan Alat Pengukur Berbasis Theory of Planned Behavior I. 19(2), 55-69.

Rochmanto, B. Al, \& Widiyanto, I. (20I5). Pengaruh Pengetahuan Produk Dan Norma Religius Terhadap Sikap Konsumen Dalam Niat Mengkonsumsi Produk Makanan Dan Minuman Halal (Studi Kasus di Kota Semarang). Diponegoro Journal of Management, 4(I), I-12.

Rohmatun, K. I., \& Dewi, C. K. (2017). Pengaruh Pengetahuan Dan Religiusitas Terhadap Niat Beli Pada Kosmetik Halal Melalui Sikap. Jurnal Ecodemica, I(I), 27-35.

Rois, E. L. H. (2016). Pengaruh Religiusitas, Norma Subyektif Dan Perceived Behavioral Control Terhadap Niat Membeli Produk Makanan Ringan Berlabel Halal. Universitas Negeri Yogyakarta.

Suparno, C. (2017). Anteseden Niat untuk Memilih Jasa Halal Beauty Center: Aplikasi Theory of Planned Behavior dan Peran Religiusitas. Media Ekonomi Dan Manajemen, 32(I), I-I3. 